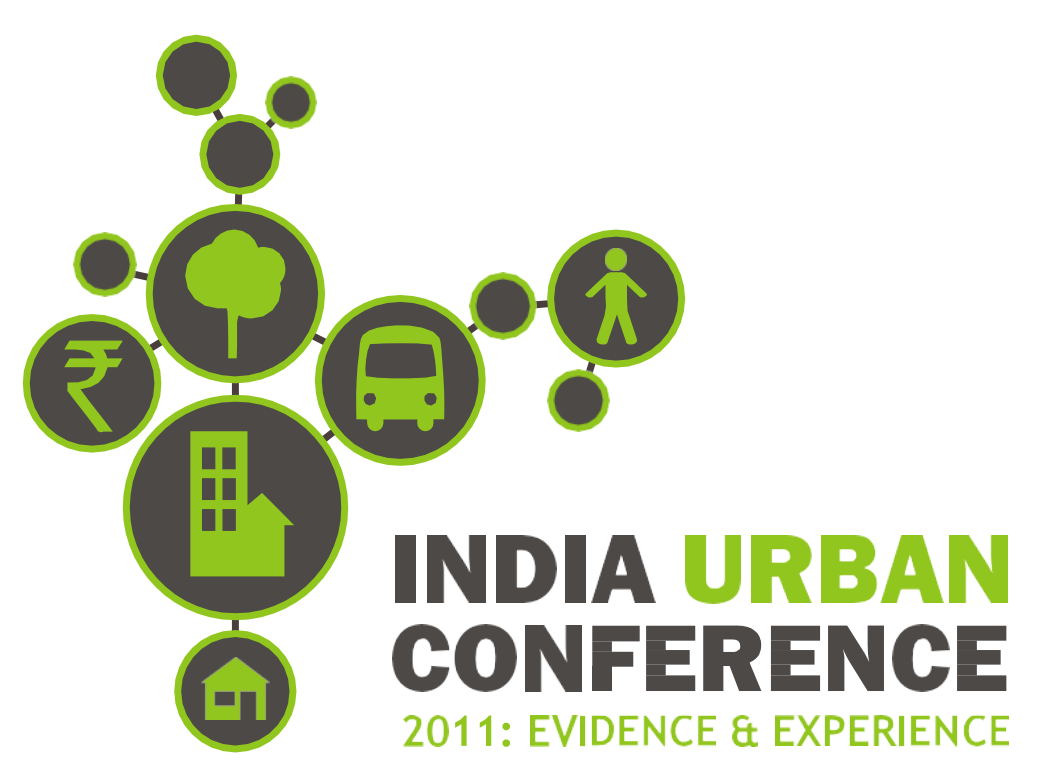

\title{
Revisiting Low Income Housing A Review of Policies and Perspectives
}

A Background Paper for 'Re-visiting Upgrading: Low-Income Housing and Infrastructure' India Urban Conference

Mysore, 17 November 2011

\section{Pritika Hingorani}




\section{Executive Summary}

This paper looks at the evolution of housing policy, particularly for lower income groups, from the time of Independence to the present day. Amongst other trends, it observes that the government's role has moved increasingly from that of a direct provider to an enabler of housing. Concurrently, there has been a steady erosion in the entitlement of the poor to government support in the provision of housing. This paper describes these policy trends, and the philosophies that have underpinned these changes over time.

In keeping with the development consensus of the time, housing provision in roughly the two decades postIndependence was heavily dominated by the state. The private sector only had a limited role to play in housing for lower income groups, although their participation and investment in housing for middle and higher income groups was significant.

During this period, housing was viewed primarily as a social or welfare good, and not one that contributed to economic growth. As a result, there was a heavy emphasis on reducing the cost of housing through innovations in building materials and construction techniques. The cost of housing was also 'reduced' by providing it at highly subsidised prices to certain target demographics.

However, a high subsidy meant that often this housing was sold off by beneficiaries to higher income groups in order to profit.

There was no official housing policy at the time and housing programs were disjointed and fragmented, targeting beneficiaries ranging from dock and plantation workers to government employees. Although over time, responsibility for implementing most of these programs was devolved to the State government, its funding came largely from the Central government. The 1956 Slum Clearance and Improvement Scheme, the 1952 Subsidised Housing Scheme for Industrial Workers and Economically Weaker Sections, and the 1959 Rental Housing for State Government Employees were some of the large schemes introduced at this time. The 1961 Rent Control Act was significant, in that, it created huge disincentives for the private sector to invest in private rental housing.

Public housing outcomes over this period were poor, with the main beneficiaries being employees of government or autonomous bodies. Since the housing delivered was often unaffordable or locationally unsuitable to the target demographic, it was often sold to higher income groups. Where slum clearance schemes failed to rehabilitate all those evicted, there was net destruction of housing stock. The almost pure subsidy approach was a drain on the exchequer and it was found that both for a lack of funds and poor implementation, new construction could not keep up with demand. Slums, as private, illegal, though affordable and often well-located housing options, proliferated over this period.

However, by the 1970s, the limits of the subsidy-driven approach were becoming apparent and the attention shifted to ameliorating the living conditions in existing slums or providing basic serviced sites on which beneficiaries could build their own housing. Slums therefore, began to be seen as housing solutions. Driven in part by World Bank-funded projects, there began to be an emphasis on cost recovery in housing projects and the limited, targeted use of subsidies for services such as infrastructure that would spur residents' own investment in housing.
With increasing financial responsibility being placed on the state government, the idea of cross-subsidisation was also introduced. Simultaneously, as the foundations of a housing finance market were laid - through the establishment of HUDCO, HDFC, the NHB and other HFIs-loan financing became another important source of funding for state governments.

Programmes introduced during this period were more integrated with targeted poverty alleviation programmes thus becoming an important part of shelter programmes. Yet the most important shift in housing delivery came in 1987 when the first National Housing Policy (NHP) envisioned a facilitative rather than a direct role for government, a greater role for private sector and more financial responsibility on the part of individual households.

In terms of outcomes, MIGs and HIGs benefited in the 70s and 80s mainly due to housing credit expansion, but housing for the poor suffered many of the problems of the previous period.

The 1990s marked several important shifts in the delivery of housing. In keeping with the trend of liberalisation, private sector involvement in housing was granted a much larger role with the Eighth and Ninth Plans reiterating the stance taken by the 1987 NHP. Although for the most part, housing programs continued as before, responsibility for implementing these was devolved to Urban Local Bodies (ULBs) under the 74th Constitutional Amendment.

There was a continued emphasis on deepening the housing finance market during this period. This was both to enable MIGs and HIGs to buy their own homes and to extend credit to the private construction industry.

The Ninth Plan explicitly recognised that urban housing and poverty require their own set of policies. It was when J NNURM was launched in 2005, that for the first timean integrated, big-ticket urban-focussed program was launched that focussed on delivering a holistic package of reforms and interventions. J NNURM focussed both on augmenting infrastructure to facilitate economic growth and on providing basic services and secure tenure to the urban poor. J NNURM also made some of the first concrete land reform policies in decades-repealing ULCRA and allowing the private sector to assemble land for the first time. However, reviews of J NNURM have been mixed and its progress on ameliorating the plight of slum dwellers has been minimal.

Criticisms of J NNURM centrearound the lack of community participation, failure to extend credit facilities to the poor, taking a fragmented project-based approach rather than an integrated approach, ignoring slum upgrading in favour of new construction and poor implementation. However, attempts to address many of these concerns are laid out in the approach to the Twelfth Five Year Plan and are expected to inform the formulation of RAY.

Beyond a simple delineation of policies, it is informative to look at the evolution in the thinking around entitlement of the poor. Many have observed that the perception of the urban poor has changed from that of vulnerable citizens to criminals encroaching on publicland. There are a number of suggested sources for this shift in thinking. One of the key reasons is a changed development ideal, as the Indian economy has moved from state-led industrialisation to market-led growth and the role of the government is redefined. These perceptions are important, in that, they inform how we think about housing, who is entitled to it, and what form government support should take. 


\section{Introduction}

As Rajiv Awas Yojana (RAY) enters its pilot phase, this paper offers a critical survey of the Indian government's past attempts at providing housing to the poor, particularly the urban slum-dwelling population. In doing so, the paper examines the philosophy and thinking that has informed previous interventions and highlights how this has changed over time. The set of questions this paper asks is necessary to understand how we currently think and have thought about low-income housing. What are the components that constitute housing? Who are the actors best involved in its design and delivery? What appear to be the modes of delivery that work, and what factors might be addressed in conjunction with shelter to yield better outcomes? Indeed, the thinking around housing has changed quite dramatically from the early postIndependence years to the present day; for instance, early housing policy was formulated in the context of limited resources, whereas today capital scarcity is much less of a concern. This raises the question: if capital is no longer the constraining factor in housing provision, then what are the most pressing concerns at present? What is the role that housing plays in our increasingly market-driven economy today?
Yet one of the most fundamental questions we must ask is: what does the government see as its role in the housing sector and who do they, and society at large, see as entitled to their support? Is adequate housing embedded as a right, a need or an entitlement in Indian policy? As a society, how do we perceive those who lack access to housing and how do we respond to their informality and their need?

In tracing this history, the paper lays more emphasis on changes in policies and approaches than on quantifying outcomes. However, since it is not possible to fit these 'changes' into neat boxes or clearly demarcated time frames, the narrative offered here is somewhat stylised and simplified to bring out the most salient points. The intention is not to disregard the complexity and conflict in views on housing and the politics of how these translate into actual policy, but merely to extract some discernable trends.

For the sake of clarity then, this paper is (artificially) divided into 3 periods that are broadly reflective of policy 'shifts': (i) the fifties and sixties, (ii) the seventies and eighties, and (iii) the post-1991 liberalisation era through to roughly the Tenth Five Year Plan. The paper also includes a section on J NNURM and on the changing framework of entitlement for the urban poor.

\section{A. Housing Policy in the 1950s and 1960s \\ Box 1: Key approaches and schemes from the First to Third Plans}

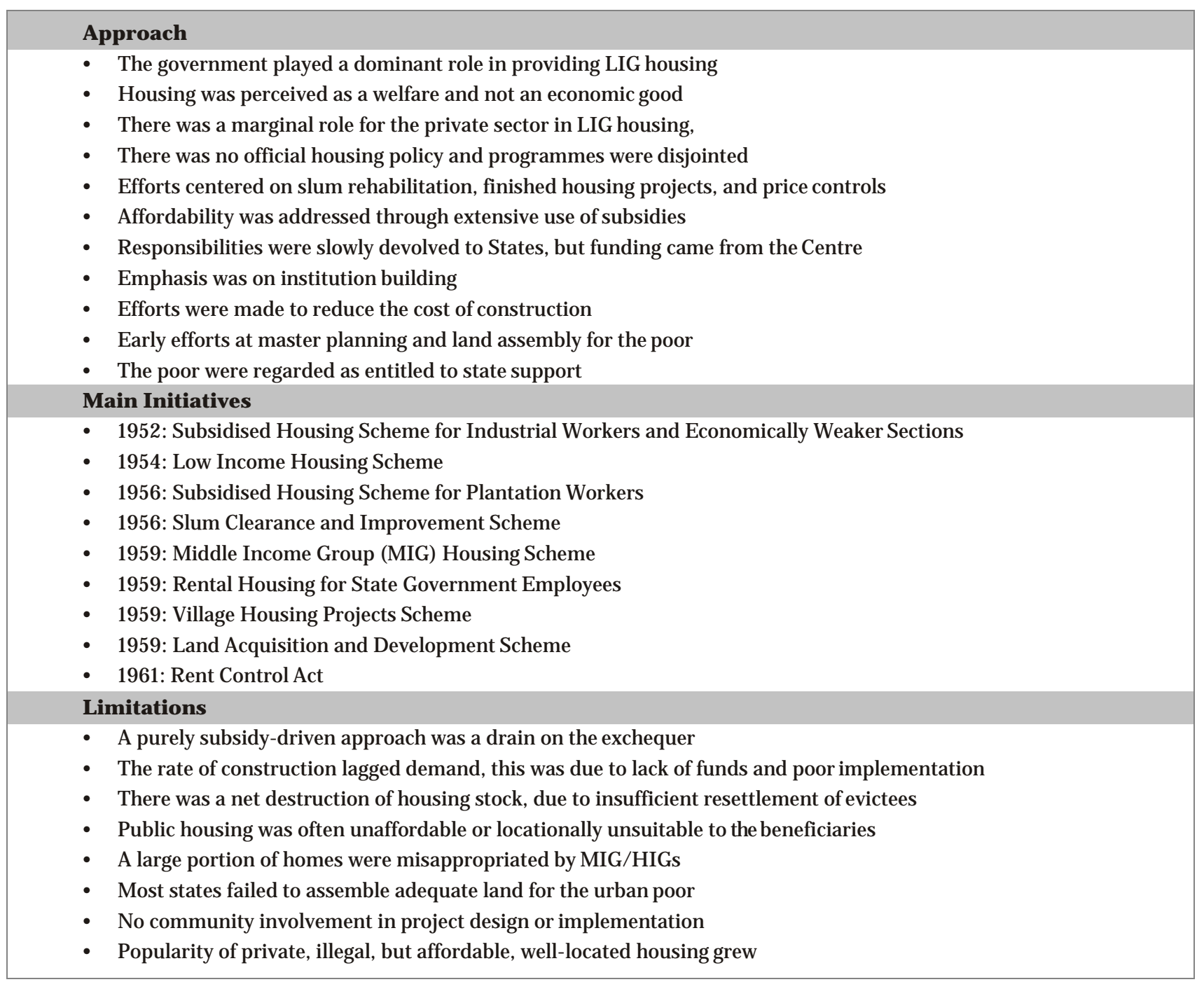




\section{Approach}

Housing provision in the two decades post-Independence was heavily dominated by the State. There were a number of reasons for this. One, there was the pressing need to rehabilitate those affected by the Partition. The First Five Year Plan (1951- 56) consequently allocated around 34 per cent of the total investment in the economy towards the housing sector alone (Sahu, Zachariah, \& Baksi, 2009). Several rehabilitation colonies were built, as were 'model' towns such as Chandigarh. These projects often included housing and both physical and social infrastructure (Rao, 2004; Sahu et al., 2009).

Second, during the period of nationalist development, there was a broad political consensus on the centrality of the state in economic development and in fostering capital accumulation. In the highly centralised welfare state of the fifties and sixties, the state was logically the primary actor in the direct provision of housing, and like with most other industries in the economy, the private sector has only a limited role. Housing policy was thus framed in the context of limited resources, with the expectation that it would evolve as the economy grew. For the time being however, as the First Five Year Plan articulated, 'it [was] not possible for private enterprise by itself to meet the housing needs of the lower income groups. The economic rent for even the minimum standard of accommodation [was] altogether beyond the means of the working class and a large section of the middle classes' (as cited in Sivam \& Karuppannan, 2002, p. 71).

In the initial years of state-led industrialisation, housing was not viewed as a productive investment or a factor in the growth of the national economy. It was viewed instead as a social or welfare good that the state sought to provide to improve the material well-being of the population (Sivaramakrishnan, 1969). This approach was reflected in the choice of initiatives developed over this period, in that, it centered on providing finished social housing projects to target populations at highly subsidised rates.

'Affordability' was perceived to be the key problem in the housing sector, particularly for lower income groups. Affordability could be disaggregated into two parts - the high cost of providing housing (because of high land and construction costs) and the low income levels that made this expense difficult to meet. At the time, the government chose to address this gap not by increasing incomes but by using large subsidies to 'reduce' the cost of housing, using direct price controls such as the Rent Control Act or extending loans on soft terms (Wadhwa, 1998).

The 1950s and 1960s were also a time of institution building. In these years the government constituted state housing boards, the Ministry of Works, Housing and Supply (now the Ministry of Housing and Urban Poverty Alleviation (MoHUPA)), the Central Public Works Department (CPWD), the National Building Organisation (NBO) and the Town \& Country Planning Organisation. In keeping with the emphasis on reducing the cost side of housing, the role of the NBO was to formulate low-cost housing designs and recommend ways to reduce costs through choice of building materials and cutting down on wasteful use of labour ('Approach to Urban Poverty', 2011).

There was no official national housing policy until 1988. However, in August 1957 the then Minister for Works, Housing and Supply made a statement on Housing Policy in Parliament. In his statement he recommended the institution of state housing corporations who would provide loan finance for housing projects with the central government providing the necessary subsidy. In keeping with this, the government shifted its policy from providing grants and loans directly to individuals to assisting state and local governments. Yet, while the responsibility for implementation of housing schemes was increasing devolved to state governments and their respective housing agencies over this period, these actors remained heavily, if not totally, reliant on the Centre for funding. Other salient recommendations were providing subsidies to those that needed it most, using indigenous building materials to the extent possible and the creation of a separate department to implement housing projects ('Approach to Urban Poverty', 2011).

In the absence of a coherent housing policy, housing was provided under a fragmented set of programs targeted at different income groups and demographics. While the initial focus of programs was broad, with programs for higher, middle and lower income groups, later programmes have increasingly focussed - at least on paper-on the poor. The Second (1956-61) and Third (1961- 66) Plans marked the beginning of increased attention to the shelter needs of lower income groups (LIGs), although the concept of Economically Weaker Sections (EWS) was only formally introduced in the Annual Plans (1966- 69).

The Third Plan also noted that housing policies be formulated with reference to economic development and industrialisation policies ('Approach to Urban Poverty', 2011).

The Third Plan recognised the availability of sufficient and affordable land as central to the success of all housing schemes. While this Plan largely continued and expanded the schemes from previous plans, it also emphasised the preparation of master plans and regional plans for metropolitan areas, industrial cities and resource areas. Importance was also given to experimenting with and developing new building techniques and on collecting housing statistics without which previous programs had been constrained. The creation of state housing boards was also given a push during this time. Since the level of housing activity by public authorities was perceived to be low, financial institutions were also established during this time to provide the requisite financial assistance to metropolitan authorities, newly established state housing boards and other urban institutions ('Approach to Urban Poverty', 2011).

\section{Major initiatives}

The first major housing program, the Subsidised Housing Scheme for Industrial Workers and Economically Weaker Sections was launched in 1952 in which the central government gave 50 per cent of the cost of land and construction as a subsidy to state government, with the rest given as a loan. The target group was families of industrial workers employed typically in mines or factories in the private sector, with incomes of less than ₹500 per month. The loans were given to industrial employers or cooperative societies of industrial workers ( 75 or 90 per cent of project cost respectively, with a 25 per cent subsidy component) to build the housing. Housing was provided on a rental basis, for a completed or open development plot. Workers could draw on non-refundable loans from their provident funds to meet the remainder of the expenditure of construction (Government of India, 1952). 
In 1954 the Low Income Housing Scheme was started which gave loans for up to 80 per cent of the cost of a dwelling unit (subject to a cap of ₹8,000) to individuals whose income did not exceed ₹6000 per annum. This loan could also be used by non-profit organisation, public bodies, cooperative societies, or by educational institutions, hospitals and the like to build rental or hirepurchase housing for their lower paid employees. It was also suggested that a portion of funds under this scheme be allocated to allow state governments develop sites for sale to low income families (Government of India, 1952). In 1956 the Housing Scheme for Plantation Workers made it mandatory to provide and maintain houses of government-prescribed standards for their workers. While larger plantations were expected to undertake this themselves, smaller plantations could avail of government loans (ibid).

During the Second Five Year Plan (1956- 61) the government launched the 1956 Slum Clearance and Improvement Scheme. This scheme borrowed directly from western experience and aimed at clearing slums and rehabilitating families in government-built housing at nominal rents (Sivam and Karuppannan, 2002; Wadhwa, 1988). The financing for this project was a 50 per cent loan and 37.5 per cent Central Government subsidy with the rest coming from the State government (later, HUDCO financing was available for this scheme) and was implemented by the respective State Housing Board and Slum Clearance Boards. Often just a skeletal structure or open development plot of between 1000 to 1200 square feet was provided with a latrine and families had to build the remaining structure in accordance with official guidelines. A limited amount of building materials were also given to families for construction (Government of India, 1956). However, the scale of construction could not keep up with the number of demolitions made and as a result the program resulted in a net destruction of housing stock. As Singh describes, in Delhi only 20.6 per cent of the population evicted was resettled by 1977 (as cited in Sivam \& Karuppannan, 2002). In addition, the sites chosen for resettlement were often far away from the where the slum dwellers had previously lived and worked, thus disrupting their means of livelihood, increasing their transport costs and uprooting them from their established social networks (ibid). This was despite the Plan recommending 'minimum dislocation' by providing homes at nearby sites so as not to disrupt employment

(Government of India, 1956). As a result, as with many of the government schemes during this period, beneficiaries often sold off the homes they received and moved back into newslums.

Other schemes during this period include the 1959 Middle Income Group (MIG) Housing Scheme which brought in the Life Insurance Corporation of India (LIC) to provide loans to individuals or co-operatives up to ₹33,000 for building houses with a cost ceiling of up to ₹43,000. Approximately 40,000 homes were built under this scheme by the Fifth Plan (Government of India, 1956). Another 30,000 homes were built under the 1959 Rental Housing for State Government Employees program that provided loans for state government to provide rental accommodation to their employees (ibid). The Village Housing Projects Scheme was launched in 1959 as a cohesive scheme for improving housing as well as infrastructure, wells and productivity in rural areas (ibid). The 1959 Land Acquisition and Development Scheme launched in the Second Plan was to receive considerable attention and financial allocation during the Third Plan. This scheme provided 10-year loans to state government to acquire and develop land on which housing and community amenities could be built (ibid).

Beyond these housing schemes, substantial investment in housing (almost ₹300 crores during the Third Plan) was made by public sector undertakings, the railways, post and telegraph departments and defense departments. A few other minor programs such as one that gave loans to Dock Labour Boards to build housing for their workers were also launched during the Third Plan (Government of India, 1961).

In 1961, the Rent Control Act was launched. This Act proved to be a major deterrent to the development of rental housing in the country. However, the intention at the time was to protect renters from eviction and rapid increases in market rent, by freezing rents at a certain level. In the long term however, these frozen rents proved insufficient to compensate landlords who, unable to evict and replace tenants, allowed their properties to fall into disrepair. While the government was supposed to be responsible for the upkeep and maintenance of these properties, their failure to do so led to poor living conditions for tenants and loss of capital and income for landlords (Wadhwa, 2009).

\section{Box 2: Private Investment in Housing}

To date, the majority of the housing stock in the country has been provided by the private sector. This contribution was recognised as early as in the First Plan, which sought to facilitate the private sector through price controls on essential building materials and allowing statutory housing boards to guarantee loans undertaken by them (Government of India, 1952).

Private sector investment in housing is both formal and informal. The Planning Commission lists the share of private investment in housing at 92 per cent in the Seventh Plan. However, the largest share of this investment is made in the informal sector that offers housing affordable to lower and some middle-income groups. In some cities, co-operative housing societies have also been a critical private player in housing.

During the 70s and 80s, newly established housing finance institutions channeled funds to the private housing sector to encourage new development and purchases for ownership. Tax incentives and increased credit targeted the demand-side constraints to private investment.

From the early nineties onwards, the private sector has been courted as a critical partner in housing development. J NNURM for the first time, involved the private sector in land assembly while the Eleventh Plan has stressed the delivery of 'Affordable Housing in Partnership'.

\section{Outcomes}

The centralised approach to housing provision - taking on responsibility from land acquisition to construction and allocation - proved to have limited success. The rate of housing construction could not keep up with growing demand. This was both as a result of failure in implementation as well as a lack of funds to meet the scale of the housing demand (Sahu et al., 2009).

Moreover, most programs did not actually benefit their target group. Often, housing was disposed off by beneficiaries who found the units 'unaffordable and unacceptable', or it was misappropriated by higher income groups (HIGs) (Wadhwa 1988). For example, 
housing provided on plots located outside the city center were too far for lower income families to commute to work on a regular basis. However, these homes were attractive to the higher income groups who could incur such costs. The large amount of subsidy involved to cover the gap between affordability and housing costs also made it very attractive for beneficiaries to sell off their housing and move back into slums (ibid). With slum clearance schemes, states often found process of acquiring slum land tedious and alternative sites were both expensive and difficult to find close by. Many slum dwellers often found it hard to pay even the subsidised rent (Sivam \& Karuppannan, 2002).

There were other problems too. The 1954 Low Income
Group Housing scheme was found to have high uptake in areas where affordable sites were available. However, as state governments reneged on their responsibility to provide such sites, this program became limited in its reach. Other programs, particularly employee-provided housing schemes, suffered from difficulty in enforcement (Government of India, 1961).

Further, as Sivam and Karuppannan (2002) note, the lack of public or community participation in project design, discouragement of international investment and the emergence of private, illegal but affordable forms of housing provision during this period also contributed to the failure to deliver.

\section{B. Housing Policy in the 1970/ 80s \\ Box 3: Key approaches and schemes from the Fourth to Seventh Plans}

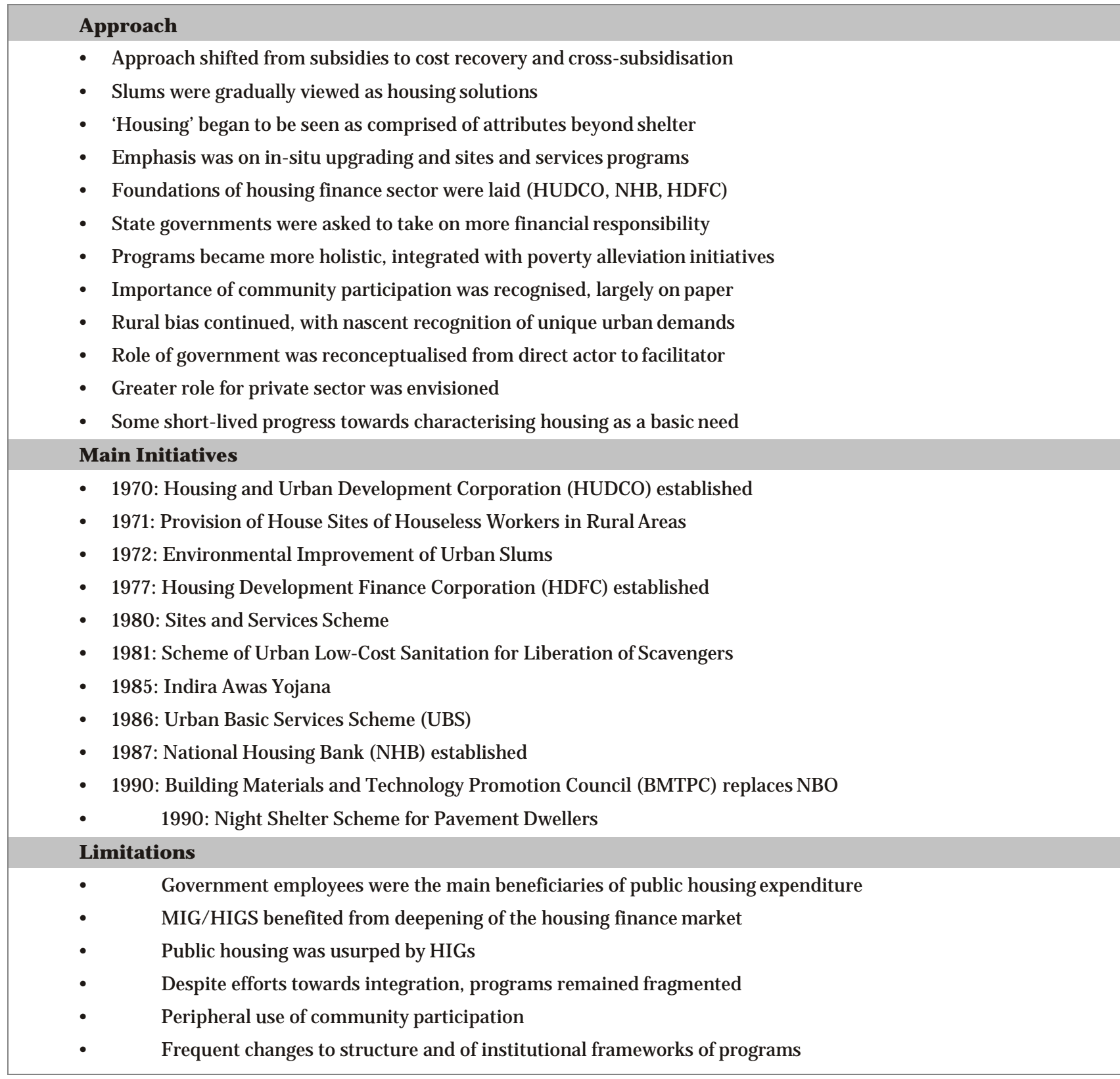


According to Rao (2004) the majority of the preliberalisation government-sponsored housing programs were introduced in the two decades after Independence. However, the 1970s and 1980s did the see introduction of two programs in particular, that marked a change in approach from previous interventions-the 1972 Environmental Improvement of Urban Slums and the 1980 Sites and Services Schemes. Before examining these and other schemes in more detail, it is important to understand the changes in domestic and international thinking around housing delivery during this time.

Concurrently, consensus around state-led development was beginning to dissipate and there was a gradual breakdown and questioning of the faith in the welfare regime. By the end of the eighties, a pro-liberalisation camp began to push for an alternate road to development with a much larger role for the private sector. They were pitted against those ideologically opposed to deregulation. The politics of this middle development period in the build-up to liberalisation are reflected in the approach to housing, with tentative steps towards encouraging private sector involvement.

\section{Approach}

Around the early 70s, the perception began to develop that given financial constraints, the high levels of subsidies provided under previous programs were no longer sustainable and publicly-provided housing could not alone be expected to solve the slum problem (Mathur, 2009). Rising land prices, and little improvement in the affordability level of the target group, would mean that going forward larger subsidies would be needed to make housing affordable; this implied either smaller program coverage or a much larger financial commitment on the government's part. Since neither option was palatable, the focus turned instead to upgrading and ameliorating the living conditions of slum dwellers (in situ upgrading) or providing land and infrastructure on which the poor could then build their homes (sites and services projects). Where slum clearance schemes continued, norms were lowered to provide smaller sized homes to beneficiaries (Wadhwa, 1988).

The recognition of the failure of government-built public housing to alleviate the housing shortage was a trend observed both domestically and internationally. A resultant change in the early 1970s then, was the growing acceptance of the importance of the informal economy (and therefore that of informal housing) in the economic life of cities (Satterthwaite, 2010). Following the achievements of the Indonesian Kampung Improvement Program in 1969, the work of the British architect J ohn FC Turner in Lima and other successful upgrading projects, slums began to be viewed as housing solutions and slum upgrading was increasingly supported by governments around the world (ibid). Planners also began to realise that for the urban poor in particular, housing' comprised attributes beyond shelter alone-to encompass location, transport, access to services and tenure. While all attributes could not be provided at once, an incremental approach could help prioritise the most important of these (Wadhwa, 1988). Slum upgrading recognised the investments made by the poor, and in avoiding relocation, preserved their access to their livelihood and other essential social infrastructure. An implicit division of responsibility saw the government responsible for tenure, location and basic infrastructure, with the poor providing the rest (ibid).
This period also laid the foundations for growth in the housing finance sector with key institutions like HUDCO, HDFC and the NHB set up to mobilise and channel investment for housing by public and private actors (these are described in more detail below). Increased emphasis on financing reflected a shift in addressing affordability from the income as well as the cost side of the problem, particularly for middle and higher income groups.

Towards the latter part of the 1970s, as the central government increasingly passed on responsibility for social housing to state governments and their housing boards, cost recovery - whether partial or full-became increasingly important. The World Bank was instrumental in driving this shift with conditions for cost recovery and targeted or limited subsidies attached to the projects they funded (Wadhwa 1988). The Sixth Plan stated that where subsidies were 'inevitable' these be given for infrastructure or sanitation facilities that encouraged residents to further invest in their homes (as cited in Wadhwa, 1988). The Plan further suggests that rather than using subsidies, programs be designed to meet the paying capacity of beneficiaries (Wadhwa, 1988). State governments also now had to rely on their internal funds, what they could borrow from newly set up housing finance institutions and what housing boards could achieve through cross-subsidisation. There was also more innovation in providing funding for housing projects. The Fifth Plan (1975-80) marked the beginning of the 'cross-subsidisation' approach with schemes for highincome groups launched with the objective of providing homes for LIG and EWS through this mechanism (Sivam \& Karuppannan, 2002)

Another shift in thinking during this time was the realisation that income growth alone could not alleviate poverty and its manifestations. The 1980s in particular recognised that shelter problems of the urban poor were inextricably linked to the lack of employment opportunities and access to basic services (Mathur, 2009). As articulated in the Seventh Plan (1985-90), a multipronged approach was necessary that expanded access to basic services, bettered living conditions in slums and created social security systems such as employment programs and the public distribution system (ibid). Programs introduced towards the end of this period gradually began to take a more holistic, integrated approach with targeted poverty alleviation programs becoming an important part of shelter programs.

The Fourth Plan (1969-74) emphasised the need to strengthen public housing agencies and introduce planning principles in order to promote systematic development of urban centres ('Approach to Urban Poverty', 2011).

The Sixth and Seventh Plans recommended a greater role for NGOs to play in community development organisations (Sivam \& Karuppannan, 2002). Increasing emphasis on community involvement in project design was again largely driven by trends in the international community. In practice, as program evaluations showed, this was rarely implemented.

Despite a continuing rural bias, there was also growing emphasis on housing in the urban versus the rural sector and the nascent recognition that urban poverty was distinct from its rural counterpart (Sahu et al., 2009). However, there were also attempts to decentralise the concentration of urbanisation under the 1979 Integrated Development of Small and Medium Town (IDSMT) 
program of the Sixth and Seventh Plan. The Sixth Plan explicitly gave priority to providing sites to the rural landless; under the Minimum Needs Programme a million landless labourers were given housing sites ('Approach to Urban Poverty', 2011). The Seventh Plan also allocated more sites to rural communities and provided construction assistance to those who already had sites (ibid).

Finally, one of the most important changes in approachfirst articulated in the 1988 National Housing Policy - and that crystallised and accelerated in the 1990s during the Eighth and Ninth Five Year Plans, was the suggested change in the government's role as direct provider of housing, funding or sites, to a facilitator of private sector investment in housing. The role of the government was increasingly envisioned to be the orchestrator of a legal, regulatory and financial framework within which housing provision by private and other actors could flourish (Sahu et al., 2009).

\section{Major initiatives}

One of the most important schemes of this period, the 1972 Environmental Improvement of Urban Slums (EIUS) sought to provide basic amenities like safe water supply, sewerage, drainage, pavements, storm water drainage, latrines and other amenities to slums settlements. The program began in 11 cities but was later expanded to cover 9 more. In 1974, implementation for this scheme was transferred to respective State governments. This program continued well into the nineties where its scope was widened under the Eighth Plan to incorporate other poverty alleviation and basic services programs (Mathur, 2009).

In 1976, the Urban Land Ceiling and Regulation Act (ULCRA) was formulated to force 'surplus' urban land onto the market. This Act put caps on the amount of land that could be held by individuals or private landowners and gave the state the right to acquire the surplus land at way below market rates. Exemptions were to be granted if the land was used to promote lower income housing. The intention was to enable the state to acquire land cheaply and then use it for housing for LIGs (Wadhwa, 2009). However, implementation was poor and more exemptions were granted than land acquired. Moreover, it was argued that the perceived scarcity had the effect of pushing land prices up higher than they would have in the absence of ULCRA (ibid). Less surplus land was distributed than was acquired. According to the budget speech of the Finance Minister for 1987- 88 'although 10 years have passed, less than one half of one per cent of the land declared surplus has actually been used for construction.' (as cited in Kumar, 1989)

Around 1980 the government launched several sites and services schemes. Although there were variations in the schemes-in some only a plot was given, while in others basic structural elements were provided-governmentprovided basic infrastructure was a feature of all. Often beneficiaries were charged a user fee for maintaining the infrastructure and also had to bear the costs of constructing their dwellings (Wadhwa, 1988). As assistance, concessional loans for up to ₹3000 per unit were given and made repayable over 20- 25 years (Government of India, 1980).

In 1981, a centrally-sponsored Scheme of Urban Low-Cost Sanitation for Liberation of Scavengers was introduced. In 1989 a related program, Integrated Low Cost
Sanitation Scheme for Liberation of Scavengers (ILCS) was launched. Both sought to eliminate the practice of manual scavenging by replacing dry toilets in urban areas with low-cost pour-flush toilets. For a number of reasons including inadequate financing, delays in loan and subsidy financing, inadequate technology and hijacking of new latrines by better off families, the programs had a poor impact. In February 2008, the scheme was relaunched as a subsidy driven scheme with targets (Mathur, 2009).

A number of important initiatives in the housing finance space were set up during this time. In 1970 the Housing and Urban Development Corporation (HUDCO) was set up to channel public funds for housing to into public sector housing projects and in making soft loans to LIGs that required longer periods of repayment. In 1977 the Housing Development Finance Corporation (HDFC) was constituted to fund individual, co-operative or associationbased housing activity. Companies could also borrow from HDFC to finance their staff housing projects (Government of India, 1974). In 1987, in conjunction with the announcement of the National Housing Policy, the National Housing Bank (NHB) was set up to as the apex housing finance institution under the Reserve Bank of Inida. Its role was to promote and regulate housing finance and mobilise greater resources for housing (Sivam \& Karuppannan, 2002). Fiscal and monetary policy (tax exemptions, housing loans) targeting MIGs and HIGs were also used during this time to encourage building of ownership-based and rental accommodation by the private sector (Wadhwa, 2009).

Since the Seventh Plan explicitly recognised the problems of the urban poor as distinct from their rural counterparts, for the first time an urban-focussed poverty alleviation scheme known as Urban Basic Services Scheme (UBS) was launched in 1986 (Mathur, 2009). UBS aimed to provide basic social services and physical infrastructure in all urban slums. Emphasis was placed on women and children living in slums-providing learning opportunities for women and pre-school programs.

Setting up of community organisations and vocational training opportunities also formed a part of this scheme (ibid).

Kumar (1989) argues that the Seventh Plan (1985-90) set the tone for a new direction in housing policy. At the time, there was growing concern about the increased income disparity, growth in black money, rapid urbanisation, and the resultant spiraling increase in land prices over which the government could exercise little control. With land prices increasing more than inflation, speculative activity had priced the poor out of the land markets (Kumar, 1989). According to Sahu et al., (2009) 'these problems required a change in policy outlook which was articulated in the Seventh Plan with a three-fold role assigned to the public sector-mobilisation of resources for housing, provision for subsidised housing for the poor and acquisition and development of land' (p.31).

Moreover, the Seventh Plan's focus on a holistic and integrated approach to shelter provision provided the impetus for the 1988 National Housing Policy (NHP). This policy looked at land, materials, finance, technology and targeted poverty alleviation as part of an integrated and comprehensive solution to the housing. Development of the housing sector as a whole was emphasised. Both the income and cost aspects of affordability were addressed; the policy suggested easy access to institutional finance at affordable rates as a pre-requisite for accelerating housing investments. It also reiterated more financial 
responsibility on the part of individual households for increasing investment in housing. Most importantly, the NHP reconceptualised the role of the government as described above.

The March 1987 Preamble to the Draft National Housing Policy (DNHP) had for the first time recognised shelter as a basic human need, ranked next to food and clothing, and closely linked with the quality of life. As Kumar notes, in this the responsibility of the state towards the poor was clearly established and it marked at least a preliminary step towards the acceptance of shelter as a fundamental right (1989). However, in the final NHP the government seemed worried that the demand to make the provision of shelter a fundamental right of the citizen, would get a boost if such a preamble was retained and this statement was removed. In 1990, the NBO was reconstituted and a new organisation, the Building Materials and Technology Promotion Council (BMTPC) was set up whose aim was to research, develop and facilitate the use and commercial production of innovative and low-cost building materials. A network of building centres was set up under this centrally sponsored scheme to help build a local delivery system. Building standards, building bye-laws and minimum plot requirements were modified to enable reductions in cost.

\section{Box 4: Criticisms of India's first National Housing Policy, 1987}

The NHP was criticised on a number of grounds, particularly for not being geared to alleviate the housing conditions of the poor. It was also thought of as an expression of good intentions that did not lay out much in terms of concrete strategies for implementation, leaving a lot of these open to the discretion of the executive (Sahu et al., 2009).

The NHP envisioned a larger role for the private sector, but it was argued that this was really an ex post justification of what was happening already. The policy stated that all past government housing policies had failed. Yet without examining the specific causes for their failure it suggested that these could be rectified by providing incentives and removing constraints to allow private sector entry into the housing market (Sahu et al., 2009).

A further criticism by Kumar (1989) is that the policy did not actually address the issue of income, but rather focussed on reducing minimum standards by legislation to make the cost of a project accessible for different income categories. He argues that even providing smaller units at the existing land prices would require a large subsidy component-which as seen before had tended to result in homes being sold off by beneficiaries. This onetime subsidy was ineffective in a dynamic context where given rising prices, the economic condition of beneficiaries would continue to deteriorate even after selling off the housing.
One of the biggest criticisms of the NHP was that it did nothing to correct the existing structural inequalities in the land market or remedy the skewed land holding pattern. Kumar (1989) argues that in seeking to repeal the ULCRA, the NHP potentially weakened the possibility of access to the land market by the poor. Not correcting access to land would continue to encourage informality and without access to land, the poor could not avail of government concessions for self-constructed housing.

\section{Outcomes}

In contradiction to what was said on paper, there were continued evictions through the 70s and 80s with households often resettled in peripheral areas. The Sixth Five Year Plan reports that homes constructed for particular income groups were generally being occupied by HIG or MIG families. Putting this down to a problem of paying capacity, the Plan suggests that future social housing schemes 'make a more realistic appraisal of the paying capacity of the recipients: this will mean a modification of standards with a view to economy' (Government of India, 1980). When actual beneficiaries were occupying the homes, their rent was often in arrears. Overall it was found that the only class of people who have benefited substantially from public sector support in housing have been employees of Government, of public sector corporations and other autonomous bodies' (ibid).

Despite an attempt to take an integrated approach to housing, policy interventions were fragmented and overlapping in their objectives and strategies. Urban poverty alleviation programs remained isolated from other related sector and area specific programs thus reducing their effectiveness. Moreover, the makeup of programs and the manner of their implementation went through frequent changes. This together with the limited use of communities in designing and implementing programs further contributed to poor housing outcomes for the lower income groups (Mathur 2009). However, the deepening of the housing finance market did have positive benefits particularly for MIG and HIG households (Wadhwa, 2009).

\section{Approach}

Although, from a policy perspective, housing programs in the 1990s were largely a continuation of previous programs, there were a number of crucial shifts in thinking during this period, some of which had taken root in the seventies and eighties. Critically, there was the growing acknowledgement of the importance of urban 


\section{Housing in the post-1991liberalisation era (through the 10th Plan) Box 5: Key approaches and schemes from the Eighth to Eleventh Plans}

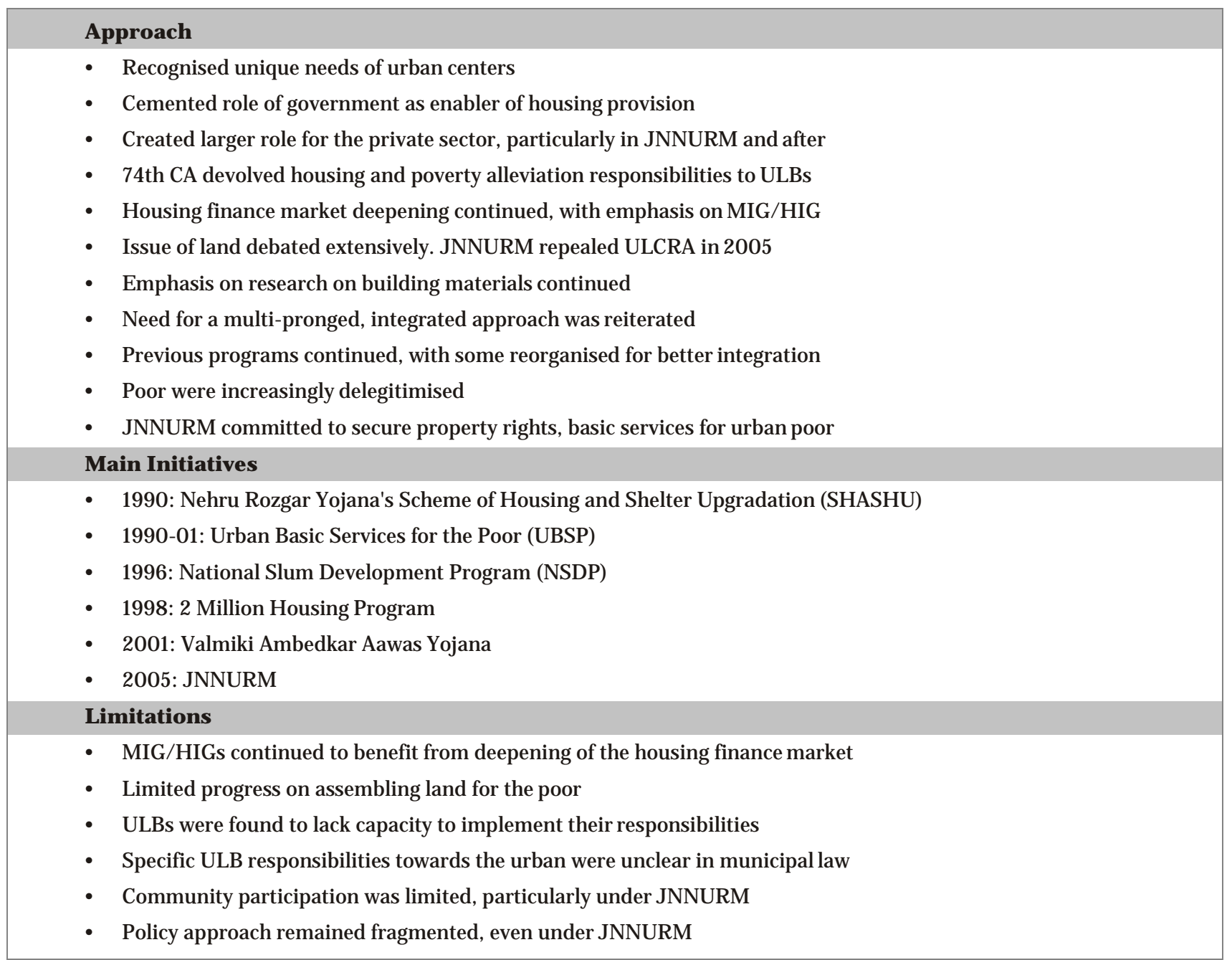

centres in the nation's economy and their need for different management, policies and laws than rural areas.

In keeping with the macro-economic trend of liberalisation, the role of the government in the housing sector was redefined and instead of direct provision of housing or serviced sites, the emphasis turned to enabling the private and co-operative housing sector. The Eighth (1992- 97) and Ninth Plans (1997-2002) both reiterated the stand taken by the 1987 NHP that the government play the role of a facilitator by creating an enabling legislative, legal and financial framework for private sector participation. However, the Ninth Plan, during which the 1998 National Housing and Habitat Policy was formulated, said that it would focus especially on households on the lower end of the housing market particularly BPL households, women-headed homes and on SC/ STs ('Approach to Urban Poverty', 2011). In these cases, direct intervention and subsidies would be used with attempts to make the flow of these funds more transparent (ibid). J NNURM marks the beginning of a serious attempt to engage the private sector in housing delivery, and for the first time allows the private sector to undertake land assembly.
Another significant change in this period was the 1992 74th Constitutional Amendment which devolved responsibility for numerous functions including urban poverty alleviation, slum upgrading, housing, management of urban services and protection of weaker sections to urban local bodies (ULBs). While devolution, particularly of financial resources has been slow, a greater role for ULBs has been a unique feature of this period and the focus of numerous urban reforms in the following years. The Eleventh Plan reiterates fuller implementation of devolution to give ULBs greater power in fostering the Plan objective of 'inclusive growth' (Mathur 2009).

There was also an increasing focus on deepening the housing finance market. Around 25 new housing finance institutions (HFIs) were set up between 1990 and the early 2000s (Sahu et al., 2009). This, together with fiscal and monetary programs to enable homeownership amongst MIG and HIG households saw lending and construction activities targeted at these households get a major boost (ibid). The Eighth Plan envisioned a greater flow of credit to the housing sector and the expansion of incentives to the private sector through HFIs ('Approach to Urban Poverty', 2011). Increasingly ULBs too have been 
encouraged to rely on capital market financing for meeting their financial obligations, which is a marked departure from previous approaches.

The issue of access to land has received continued attention through the Plans. In the years preceding the 1994 National Housing Policy there was a revived discussion around the issue of land and how to remedy some of the structural inefficiencies seen as responsible for proliferation of slums. Some suggested that the right to transfer landed or immovable property be nationalised and certain minimum housing standards be recognised as part of a citizen's fundamental right (Sahu et al., 2009). While the 1994 document did acknowledge these concerns, it mainly proposed repealing ULCRA (which was undertaken in several states) and modifying the RCA to increase investment in rental housing and better balance the needs of tenants and landlords (ibid). J NNURM finally took the step of repealing ULCRA in 2005.

The Eighth and Ninth Plans attempted to remedy the fragmented nature of previous housing and urban poverty interventions and link income upgradation with shelter programs. The Eighth Plan recognised the importance of integrating informal sector occupations with the rest of the formal urban economy and advocated better coordination of programs on employment, housing and infrastructure (Mathur, 2009). For example, EIUS was expanded under this Plan and dovetailed with an expanded UBS scheme (now called Urban Basic Services for the Poor [UBSP]) that focussed on mother and child care, nutrition, education and assistance to the handicapped and destitute (ibid). However, it was with the introduction of J NNURM in the Tenth Plan (2002- 07), that for the first time an integrated, big budget schemes for housing, infrastructure, poverty alleviation and systematic urban reform was undertaken.

\section{Major initiatives}

The 1990s began on an encouraging note for the urban poor. In 1990 the VP Singh government began a program to provide identity cards to slum dwellers with the intention of legalising their tenure and upgrading their access to basic infrastructure. However, his government, and consequently this program, was short-lived (Ramanathan, 2006).

In 1990 the new draft National Housing policy for the first time recognised the economic contribution of the housing and construction sector in generating employment. The policy aimed to:

(i) to prevent luxury housing (for which the residential plot size was reduced from 2000 sq.m to 120 sq.m)

(ii) to enable self-help housing through fiscal and monetary measures for HIGs and MIGs

(iii) to make the state directly responsible for providing housing for the poor

(iv) to amend ULCRA to bring about better supply of urban residential land

(v) to strengthen both formal and informal sources of financing and

(vi) to encourage rental housing (Sivam \& Karuppannan, 2002). This was not very different from the 1988 housing policy however strategies to achieve stated aims were clearer and the document voiced more concern for poorer citizens.

Under the Annual Plans of (1990-91) and (1991-92) the previous UBS program was enlarged with 100 per cent
Central funding to form Urban Basic Services for the Poor (UBSP) as described above. Under the Eighth Plan, EUIS, UBSP and 1990 Nehru Rozgar Yojana (NRY), an employment scheme containing a component called 
'Scheme of Housing and Shelter Upgradation (SHASHU)' were the primary urban and poverty alleviation programs. Assuring secure tenure and designing cost recovery mechanisms were recognised as crucial to the long-term sustainability of EIUS (Mathur, 2009).

In 1997 the National Slum Development Program (NSDP) sought to augment state government funds for upgrading with additional Central money. In keeping with the Eighth Plan findings that programs were still fragmented, the shelter upgrading components of NRY and the Prime Minister's Integrated Urban Poverty Eradication Program were incorporated into NSDP. NSDP focussed on providing physical amenities, community infrastructure and social amenities, shelter upgradation, skill upgradation and training of urban poor women and encouraged the involvement of NGOs, community based organisations (CBOs) and private bodies (Mathur, 2009).

Under the 10th Plan in 2001, another centrallysponsored construction and upgrading scheme, Valmiki Ambedkar Awas Yojana (VAMBAY) was launched that targeted below poverty line households lacking adequate shelter. It also aimed to provide health services and access to community toilets through Nirmal Bharat Abhiyan with 20 per cent of the funding under VAMBAY to be allocated to sanitation. The program was the first of its kind to be implemented through a 50 per cent Central Government subsidy with the remaining contribution coming from state or local governments or through a loan from HUDCO. State governments were required to set up the implementation machinery, arrange land where required and organise the credit component. The state's contribution was in line with the size of their slum population and finances could be obtained through loans if required, such as through HUDCO (Mathur, 2009).

In 1990, the Night Shelter Scheme for Pavement Dwellers provided loan and subsidy funding for the construction of night shelter and sanitation facilities for pavement dwellers. HUDCO is the implementing agency for this scheme which is funded using 20 per cent Central funding with the rest coming from the implementing agency or through a HUDCO loan (Mathur, 2009)

The Two Million Housing Program (2MHP) launched in 1998 is a loan based scheme aimed at facilitating the construction of two million homes every year using funding from HUDCO and HFIs.

\section{Outcomes}

Despite the recommendations of the 1994 NHP, little progress was made in the regulatory framework governing land.

Deepening of the housing finance market has had positive impacts mainly for the middle and higher income groups. Since mortgage finance at the time required clear title to property, approval of building plans by the local authority and a regular stream of monthly income, this mode of financing was not accessible to the urban poor. Housing finance was thus concentrated amongst these groups and particularly in the larger urban centres. On the supply side expansion of housing finance led to greater affordability of homeownership for the MIG due to increased supply and competitive interest rates. However, while the housing stock increased, so did the population which led to overcrowding (as cited in Marshall, 2010), and it appears that a portion of the new stock lay vacant due to speculation. 


\section{The 10th Plan and J NNURM}

The Tenth Plan, in estimating the total housing shortage in the country, observed that 90 per cent of this pertained to LIG and EWS households. The Plan noted that despite devolution of responsibility to ULBs there were no specific provisions in municipal law for dealing with issues related to the urban poor and slums. It highlighted the need for capacity building within municipal bodies and other agencies responsible for meeting the needs of the urban poor. Uncertainty regarding the institutional arrangement for slum improvement programs between the different agencies - slum boards, housing boards, development authority, municipal body, etc.,-had led to problems in implementation while the failure to provide for the poor in the town planning process and a lack of commitment to tackle the slum issue had led to poor outcomes despite sustained investment (Mathur, 2009). The Plan reiterated the merit of an integrated approach in dealing with urban poverty.

\section{Box 6: What is J NNURM?}

The J NNURM launched in 2005 is a scheme designed to make catalytic investments and provide reform guidance that will make Indian cities 'world class'. The scheme has two sub-missions: the Sub-Mission for Urban Infrastructure and Governance (UIG) administered by the Ministry of Urban Development (MUD), and the SubMission for Basic Service to the Urban Poor (BSUP) administered by the Ministry of Housing and Poverty Alleviation (MoHUPA). The latter sub-mission focuses on integrated provision of basic services including shelter and security of tenure to slum dwellers. In non-mission cities covered by MoHUPA, these activities are carried out under the Integrated Housing and Slum Development Program (IHSDP).

J NNURM is predicated on the rationale that for cities to serve as growth centers for the economy, an adequate level of infrastructure is crucial. J NNURM holds that cities must also undertake critical urban sector reforms that will enable better governance and management as for too many years they have been governed by archaic laws that do not correspond with current urban realities. ULBs must play an important role in managing urban centers and the increased investment that they will draw both under J NNURM and as a result of their increased economic salience. J NNURM also envisions achieving five of eight Millennium Development Goals on poverty, health and gender equality in mission cities (Mahadevia, 2006).

J NNURM at present covers 65 cities (Seven class 'A' mega-cities, 28 class $B$ metros and 25 class $C$ urban agglomerations). To access J NNURM funding, cities must make certain mandated reforms in addition to which they may implement some of the optional reforms. At the state level it is mandatory for states to repeal ULCRA, reform the RCA and to reduce stamp duty. Two mandatory reforms at the ULB level that important for the urban poor are: (i) provision of basic services to the urban poor including security of tenure at affordable prices, and (ii) internal earmarking within local bodies' budgets for basic services to the urban poor. While both are laudable and the former might be achieved, it is not clear how the latter will happen particularly with the repeal of ULCRA (Mahadevia, 2006).

In terms of the process, cities must first formulate a City Development Plan (CDP) laying out their strategies and policies and then prepare a Detailed Project Report (DPR) for identified projects that will then be implemented by
ULBs. All projects should have its life cycle costs-capital outlays and O\&M costs-recovered. (Mahadevia, 2006)

It was against the background of these observations that J NNURM was launched. In keeping with the reflections of the Plan, J NNURM seeks to modify the laws that have impeded or distorted the functioning of the land and housing markets and caused slum proliferation, confer property rights on the poor, put in place governance structures that are sensitive and responsive to the needs of the urban poor, eliminate the pricing regime that has blocked investment in urban infrastructure and implement tax reform particularly in property taxation to improve the fiscal situation of municipalities who now shoulder greater responsibilities (Mathur, 2009). J NNURM also mandates the repeal of ULCRA and advocates major reforms in urban land use policies and tenurial systems with the objective of earmarking land for the urban poor and providing security to slum dwellers.

However, the results and reviews of J NNURM have been mixed, and the suitability of some of the measures it adopts has been questioned. Criticisms centre on the following points (drawn from 'Approach to Urban Poverty', 2011 and Mahadevia, 2006):

- Fragmented, project-based approach: Despite the recommendations and policy directions of previous Five Year Plans and J NNURM itself, the mission is said to suffer from the lack of an integrated approach. Related issues like land, health, education and employment are being handled by separate Ministries at the central level and implemented in silos at the local level. A clear strategy on convergence is required, and replacing the project-based approach with a more holistic one that takes an integrated view of city development would improve outcomes.

- A one-size fits all approach: J NNURM focusses on 65 cities of varying sizes and with different problems. While slums are a problem in the larger cities, in smaller towns the question of poverty alleviation is more pressing. It would be preferable to develop context-specific strategies or introduce greater flexibility in program design.

- Lack of community participation: J NNURM is said to have failed to involve communities in the design, planning or implementation stages of its projects. The lack of community consultation, particularly in the case of resettlement, has led to delays in housing delivery and the selection of projects that were not best suited to the needs of beneficiaries. Moreover, as per the established procedure CDPs are to framed by external consultants and therefore lack a consultative process.

- Emphasis on new construction over in-situ redevelopment: Despite the priority given to in-situ redevelopment in the mission, in practice, BSUP and IHSDP have emphasised construction of new dwelling units for the poor. Delays in implementing such programs have led to cost escalations which in turn mean housing is not delivered on the required scale and becomes unaffordable to the target demographic. It was recommended that equal, if not more emphasis, should be placed on in-situ upgrading and other options such as rental and incremental housing.

- Inadequate credit and lending facilities: A key factor in enabling affordability is extending credit facilities that are accessible and suited to the needs of the urban poor. 
However, micro-financing options have largely been ignored by J NNURM.

- Land reforms have been inadequate: It has been argued that the critical issue of land is not adequately addressed by the mission. Some argue that the repeal of ULCRA will make it difficult to bring affordable land into the hands of ULBs for housing the urban poor or to useas a source of revenue (Mahadevia, 2006). However, given the performance of ULCRA to date, its repeal may have little impact. Other options for augmenting supply of affordable land-the earmarking of 20-25 per cent of developed land and the simplification of legal and procedural frameworks for conversion of land from agricultural to non-agricultural purposes are only optional reforms under J NNURM. The mission has also not looked at how cities should deal with slums on central government land, which has been a particularly difficult task.

- CDPs are divorced from the urban planning process: It is argued that without a mandated link between the CDP and the urban planning process of the city, CDPs have become redundant over time. Although CDPs are meant to be dynamic documents, few cities have taken the initiative to update theirs, particularly as the mission ends in 2012.

- No clear resettlement policy: J NNURM lacks a clear resettlement policy. Projects funded under the UIG submission might require eviction of slum dwellers in which case clear policies on their rehabilitation are necessary. Particularly since land costs are not covered by J NNURM, slum land might prove a soft target.

- Lack of capacity: The lack of capacity at the central, state and ULB level for implementation and program guidance has been a major stumbling block for J NNURM. Expenditure on capacity building has been low; several state governments have complained funding delays mean they are heavily reliant on externallyfunded capacity building projects.

- External borrowing and alternate financing by ULBs has been low: J NNURM encourages local governments to borrow in commercial financial markets but few have been able to do so. Similarly, few have augmented their finances through user charges, monetisation of urban land and property taxes as envisioned. Moreover, governments that are not fiscally solvent or lack the capacity to manage this process might jeopardise their financial situation which further impacts the urban poor.

- Progress on key reforms has been slow: Reforms related to property tax, governance, local accountability, and the devolution of functions to ULBs have not been implemented to the extent envisioned. Only very few states have set up their Project Management Units (PMUs) and cities their Project Implementation Units (PIUs). These units were designed to provide dedicated manpower for implementing J NNURM.

- Projects have faced significant delays in implementation: Increases in raw material costs relative to government estimates have left state governments struggling to meet the additional expenditure thus delaying projects. Appraisal agencies such as the BMTPC that are responsible for project approval are understaffed leading to further delays.

- Potential for misuse of earmarked funds: It is recommended that the accounting rules be changed for the BSUP Fund so it is not diverted for other uses.

- Cities are free to decide their level of investment in BSUP: The selection of projects and level of borrowing under UIG and BSUP is left to the discretion of cities with the result that more borrowing may be done for UIG than BSUP as per the priorities and compulsions of the city.

While J NNURM has greatly increased investment in urban infrastructure, from a shelter and basic services perspective it has had limited impact. Many of the learnings from J NNURM are incorporated into RAY, which unlike J NNURM is purely a shelter and basic services-focussed mission.

\section{E. A changing framework of entitlement for the urban poor}

Although evictions and inadequate resettlement have rendered thousands of families homeless and vulnerable in every decade since Independence, the frequency and scale of evictions seems to have picked up pace over roughly the past ten or fifteen years. In 1996 for example, in an effort to 'regain the support of the urban middle classes' and 'make Bengal a safe investment destination', the state government authorised the Kolkata municipal authorities and police to demolish all the city's hawker stalls (Bandyopadhyay, 2009). Under 'Operation Sunshine' as this project was titled, hawkers received no compensation or rehabilitation for their lost commercial space. In 2004, more than 90,000 hutments were razed to the ground on the orders of the Maharashtra Chief Minister without any prior legal notification and no alternate accommodation. As this section will describe, this shift in policy or approach-whether official or unofficial-stems from a deeper change in the perception of the rights of the urban poor and the state's entitlement towards them.

\section{Where do we locate the sources of this shift?}

One might be the changed development ideal, as the country has moved from a largely state-led growth model to an increasingly market-driven economy. At the time of Independence, there was considerable unity in the Gandhian notion that in a just state the collective interest must take precedence over individual interests' (Nayyar, 1998). Since it was believed that the logic of the markets meant exclusion of a significant share of the population, especially the poor, the state was seen as the logical and necessary partner in development (Degnbol-Martinussen 2001). Under this belief system, the state had a particular responsibility to defend and provide for its more vulnerable citizens. By the 70s and 80s however, poor growth rates and the capture of economic rents by powerful factions had begun to shatter faith in state-led development. In the vacuum created by the lack of a development ideal, competitive populism and an 'overwhelming reliance on patronage' took centre stage (Nayyar, 1998). Partly motivated by the upward spiraling of subsidies and transfers being disbursed by the state, there gradually came a shift in thinking amongst some of India's policy elite that 'market forces would allow India to realise its development challenges more efficiently than government controls' and that liberalisation, by 'reducing the amount of subsidy up for grabs' might help drive out some of the redistributional factions that were having a blocking effect' on growth (Singh, 1991; Khan, 2000).

No doubt, liberalisation reforms have set the Indian economy on a higher growth trajectory. Yet, as the government increasingly settles into the role of an enabler 
and the safety net of the welfare state is rolled back, the poor are being asked to navigate the market to provide for themselves, in what Nikolas Rose calls 'selfresponsibilisation' (as cited in Bhan, 2009). That the state has a responsibility to help level a playing field torn apart by generations of inequality-by directly providing even the basic requirements to participate in market growthhas been ignored. Thus, under the new market logic, the role of the government and their responsibility to the poor is redefined and reduced.

In the (almost) fundamental shift to a neo-liberal rationality, access - to even the most basic of human needs - is increasingly determined by the capacity to pay . As the private sector has grown in strength, the government is increasingly looking to them to provide fundamentals like infrastructure and housing. Yet to what extent can the logic of the market display sensitivity to the needs of the poor? Indeed, critics of J NNURM note that in its imagination of a more efficient, privatised urban government, it becomes much more difficult to make a case for the importance of poverty understood separately from the market (Bhan, 2011).

A second place to locate this shift is in legal pronouncements that have increasingly portrayed the poor as illegal - pitted as unscrupulous elements stealing from honest citizens who pay for land and a house. (See Box 7). As the poor take on the attributes of criminals, the denial of their text-based rights is justified and the state is absolved of their responsibility to provide resettlement in the case of eviction. As the tone and content of these pronouncements infiltrate and reinforce popular and media opinion, the poor are no longer perceived as vulnerable citizens with equal rights and claims to public infrastructure and basic services but as encroachers worthy of punishment. That their 'informality' is created by the state in their failure to provide land and basic services is summarily disregarded (Ramanathan, 2006). However, it is important to note that while court rulings (particularly the later ones) have played a role in framing, even polarising, public opinion, their biggest impact has been in Delhi and the surrounding areas.

\section{Box 7: Legal Rulings on the Rights of the Urban Poor}

In 1982, at a seminar on 'Law, Planning and Urban Development' in Mumbai, J ustice Krishna Iyer made the point that the egalitarian essence of the Constitution necessitated that social justice inform our idea of reasonableness (Abraham, 1982). Thus, he argued, while there can indeed be classification of lands as pavements, streets, parks and playgrounds set apart exclusively for social use' when the government is 'confronted by the claims of those who do not have one square metre of earth to stand on, the egalitarian justice of the Constitution will refuse to accept the basis of classification whereby persons without title to land are evicted.' (as cited in Abraham 1982). This was not to say that 'intruders' were 'constitutionally barricaded' from being evicted but that the 'displacement be accompanied by fair reasonableness', i.e., rehabilitation or a welfare program under which alternate housing was provided (ibid).

J ustice Iyer's comments could set no legal precedent. Yet his sentiments were echoed in a number of rulings in the early 1980s, as the Supreme Court began to emerge as a champion of the country's poor.

The 1985 Olga Tellis vs Bombay Municipal Corporation (or 'pavement dwellers case') was the first major legal battle between pavement/ slum dwellers and the public agencies who sought to evict them. As Ramanathan (2006) writes '[this] judgement reflect[ed] the struggle of the court in installing the right to shelter within the fundamental rights framework, while yet allowing the state the power to clear the streets and spaces in the interest of urban order.' There were two sides to the ruling. On the one hand, the court made strong statements linking the right to livelihood with the right to life and asserted, 'to lose the pavement or the slum is to lose the job' (as cited in Ramanathan, 2006). Moreover, the court argued, pavement and slum dwellers did not occupy the land to pursue an illegal occupation but rather because of the state's failure to provide them with alternative accommodation, their failure to implement the Master Plan which had created concentrations of business and commercial spaces to which people naturally flocked, and their neglect of rural programs of employment, health and education (ibid).

On the other side, the court held that no person had the right to encroach on any place reserved or earmarked for a public purpose such as a garden, footpath or playground. Thus in its final ruling while the court did not prevent demolitions, it strongly advocated resettlement and the minimisation of hardship during this process. Eviction was to be preceded with a notice giving the defendant an opportunity to appear before the court. Moreover, while it was not necessary to provide alternate sites prior to eviction, the state government had to provide alternatives to those who had lived on the site prior to 1976. Slums which had been in existence for a long time, around 20 years or so, were not to be demolished until the land on which they stood was required for a public purpose and resettlement was to be provided in case of demolition. The court also impressed that low income shelter and slum upgrading programs be actively pursued (ibid).

On the same day in 1985, a similar ruling was passed in Tamil Nadu. In K Chandru vs. State of Tamil Nadu, the court ruled that slums should be improved and evictions were only to be undertaken where existing slums could not be improved. Alternative accommodation must be provided before evictions could take place (ibid).

The latter 80s began to see movement, however tentative, towards establishing housing or shelter as a basic need, if not a fundamental right. In 1989 in Shantistar Builders vs. Naryan Khimalal Totome and others the Supreme Court ruled that '.. reasonable residence [was] an indispensable necessity' for human development required to fulfill 'the right to life' (as cited in Bhan, 2009). This 'right to life' it was clarified in the 1996 Chameli Singh vs State of Uttar Pradesh, 'in any civilised society implies the right to food, water, decent environment, education, medical care and shelter' (as cited in Bhan, 2009).

In 1990 the Law Commission published a report that advocated for a law that would give statutory basis to slum dwellers' right to resettlement following destruction of their homes. The report argued that there was neither any legislation to protect slum or pavement dwellers in the event of eviction, nor was there any social safety net to support them if they lost their home. On grounds of 'constitutional values', humane considerations' and 'social justice', local authorities should be required, by way of central legislation, to rehabilitate those evicted (as cited in Ramanathan, 2005). Further, the report argued, pavement dwellers should not be 'disturbed unless it [was] inevitable to do so in the context of some emergent situation' (ibid). Despite this plea however, no law was formulated and the report was quickly forgotten. 
However, by 1993, the state's attitude (as articulated in these rulings) seemed to have changed drastically. J ustice Kirpal speaking along with a fellow judge in Lawyers' Cooperative Group Housing Society vs Union of India penned, '[i]t appears that the public exchequer has to be burdened with crores of rupees for providing alternative accommodation to jhuggi dwellers who are trespassers on public land' (as cited in Ramanathan, 2006). The judges ruled that beneficiaries should not be given land on leasehold as was customary when resettlement was done, but on license, with "no right in the license to transfer or part with possession of the land in question" (ibid).

In Hem Raj vs Commissioner of Police in 1999, the judge ruled, When you are occupying legal land, you have no legal right, what of talk of fundamental right, to stay there a minute longer' (as cited in Bhan, 2009). Slums therefore were no longer seen as the last resort by citizens who the state had failed to provide for, but as outright thefts of public land at the expense of other citizens. It was on this basis that the alternate 'public use' of encroached land for the 'good and honest' citizens of the city was prioritised and justified as in the case of Almitra Patel vs Union of India in 2000.

This 2000 ruling, also authored by J ustice Kirpal equated the cleaning up of slums with cleaning up the city. The case was actually the courts' intervention to secure a landfill site for the Municipal Corporation of Delhi (MCD) for free from other state agencies who were demanding unaffordable market prices for their land. That the court would intervene to make land affordable for a service that was deemed to be 'in the interest of public health' but not in making it land affordable to the urban poor brought into sharp focus the changed definition of 'public interest'. It was argued that the use of large areas of public land' for 'private use free of cost' by slum dwellers meant that the process of resettlement was akin to 'rewarding a pickpocket' (as cited in Ramanathan, 2006).

Beyond the court rulings, a third source for this shift has been what Roy (2004) has called an 'aestheticisation of poverty' - a phenomenon in which the physical attributes of the slums as messy, disorganised or unhygienic are imposed as judgments on the character of their inhabitants. This simplification ignores the politics and neglect that have caused the slums in the first place. For aspirational, middle class citizens clamouring to live in a 'world-class city', slums (and their residents) become an eyesore that conflicts with their visual imagination of this kind of city. With their elevated citizenship, the rich can then invoke the values like hygiene or public health and expect the state to intervene to protect them from the illegal slum dwellers. As the visual of the slum and the character of its inhabitants are conflated, so the worldclass city is consumed merely as its outward appearance of cleanliness, order and leisure, disregarding issues of egalitarianism and access.

Thus, the years since Independence have seen a steady, if not linear, erosion of the entitlement of the urban poor that in turn, has challenged their claim to the city. Indeed, how we view the poor, their investments and their entitlement, has critical implications for housing policy choices. The staggering housing 'shortfall' calculations of the Tenth Plan, for example, implicitly delegitimises the housing solutions the poor have devised for themselves. Going forward, how this housing is read (as a solution in the face of insecurity or theft of public land) and who is regarded as culpable (the state for its failure to deliver housing or the slum dweller for providing for themselves) will be the foundation on which the form and acceptability of any future policy will rest. 


\section{Bibliography}

Abraham, A. (1982). Slum Dwellers and the Constitution. Economic and Political Weekly, 17(33), 1308- 1310.

Abraham, A. (1985). Housing: For the Poor? Economic and Political Weekly, 20(6), 226- 228.

Bardhan, P. (1984). The Political Economy of Development in India. Oxford: Basil Blackwell.

Bhan, G. (2009). "This is no longer the city I once knew". Evictions, the urban poor and the right to the city in millennial Delhi. Environment and Urbanization, 21(1), 127- 142 .

Degnbol-Martinussen, J . (2001). Policies, Institutions and Industrial Development: Coping with Liberalisation and International Competition in India. London: Sage Publications.

Government of India (1952) First Five Year Plan 195156, New Delhi

Government of India (1956) Second Five Year Plan 1956- 61, New Delhi

Government of India (1961) Third Five Year Plan 196166, New Delhi

Government of India (1969) Fourth Five Year Plan 1969- 74, New Delhi

Government of India (1974) Fifth Five Year Plan 197479, New Delhi

Government of India (1980) Sixth Five Year Plan 198085, New Delhi

Government of India (1985) Seventh Five Year Plan 1985-90, New Delhi

Government of India (1992) Eight Five Year Plan 199297, New Delhi

Government of India (1997) Ninth Five Year Plan 1997-2002, New Delhi

Khan, M. and Sundaram, J .K. (eds). (2000). Rents-RentSeeking and Economic Development: Theory and Evidence in Asia. Cambridge: Cambridge University Press.

Kumar, A. (1989). National Housing Policy: The Implications. Economic and Political Weekly, 24(23), 1285- 1291.
Mahadevia, D. (2006). NURM and the poor in globalising mega cities. Economic and Political Weekly, 41(31), 33993403.

Mathur, O.P. (2009). Slum-Free Cities: A New Deal for the Urban Poor. Retrieved from

www.nipfp.org.in/ opm_files/ .../Final\%20Poverty\%20Rep .pdf

Marshall, S. (2010). Of squatters and schemes: considering city-level strategies for housing the poor in India. (Masters Dissertation). Retrieved from DSpace@MIT http:/ / hdl.handle.net/ 1721.1/59580

Nayyar, D. (1998). Economic Development and Political Democracy. Interaction of Economics and Politics in Independent India. Economic and Political Weekly, 33(49), 3121-3131.

Ramanathan, U. (2006). Illegality and the urban poor. Economic and Political Weekly, 41(29), 3193-3197.

Ramanathan, U. (2005). Demolition Drive. Economic and Political Weekly, 40(27), 2908-2912.

Rao, P.S.N. (2004). Transformation of Housing Policy in India--the Trend Towards Market Mechanisms. Retrieved from www.housingauthority.gov.hk/ hdw/ihc/pdf/rhk.pdf

Sahu, G., Zachariah, Y., and Sandipan Baksi. (2009).

National level background document on urban issues and concerns. Retrieved from tissuirf.org/ downloads/ NLBD.pdf

Satterthwaite, D. (2010). Upgrading Slums: With and For Slum Dwellers. Economic and Political Weekly, 45(10), 1443-1445.

Sivaramakrishnan, K.C. (1969). Urban Housing: Challenge and Response. Economic and Political Weekly, 4(36), 1443- 1445.

Sivam, A. \& Sadasivam K. (2002). Role of state and market in housing delivery for low-income groups in India. J ournal of Housing and the Built Environment, 17(1), 69- 88.

Wadhwa, K. (1988). Housing Programmes for Urban Poor: Shifting Priorities. Economic and Political Weekly, 23(34), 1762- 1767.

Wadhwa, K. (2009). Affordable Housing for Urban Poor. Retrieved from www.spa.ac.in/ NRC/ ThemePaperAffordableHousing.pdf 


\section{INDIAN INSTITUTE FOR HUMAN SETTLEMENTS}

IIHS aims to establish India's first privately funded and managed National Innovation University focussed on the challenges and opportunities of urbanisation in all its aspects.

The University is intended to be a globally ranked institution.

The IIHS University will host an integrated programme of quality campus based education and research, practical training for working professionals, distance and blended learning, and a whole array of consultancy services. The University will have a strong interdisciplinary orientation, incorporating both theory and praxis.

The Academic Programme will consist of globally benchmarked Bachelors, Masters and Doctoral Degrees in Urban Practice based on a wide set of disciplines and practice areas central to India's urban transformation. The Masters and Undergraduate programmes of the University will provide a deep understanding of a wide range of topics including the economic drivers of urbanisation, urban planning, the physical infrastructure, transportation systems, the social infrastructure and social justice, land and housing, public safety and disastermanagement, the environment and sustainability, and law and urban governance.

The applied research programme will help create a new generation of interdisciplinary researchers and a corpus of relevant India-centric knowledge.

IIHS's deep commitment to the process of social transformation in India by providing educational opportunities to deserving learners irrespective of economic and social status, gender, age or disability. 
